\title{
PReS-FINAL-2016: Bone mineral status in a long-term follow up of juvenile dermatomyositis patients
}

\author{
VA Kristensen ${ }^{1}$, S Nielsen², T Herlin ${ }^{3}$, P Mathiesen ${ }^{1 *}$ \\ From 20th Pediatric Rheumatology European Society (PReS) Congress \\ Ljubljana, Slovenia. 25-29 September 2013
}

\section{Introduction}

Juvenile dermatomyositis (JDM) is a rare autoimmune disease with the onset in childhood involving chronic inflammation of striated muscle and skin. The disease is often leading to severe disability, prolonged decreased physical activity, which together with chronic inflammatory activity, and long-term medical treatment with glucocorticoids, contributes to the well-known risk factors for developing osteopenia or osteoporosis. Only a few studies have followed JDM patients into adulthood.

\section{Objectives}

The objective of the present study was to investigate the long-term outcome on bone mineral status in a Danish cohort of patients with JDM.

\section{Methods}

A total of 49 patients with JDM diagnosed between 1976 and 2005 were investigated. The female/male ratio was 2.5. The mean age at disease onset was 7 years (range 1.5-16 years) and the mean disease duration was 3.7 years (range $0.7-9$ years). The follow-up time ranged from 2 years to 36 years (mean 7 years). Bone mass density (BMD) $(\mathrm{g} / \mathrm{cm} 2)$ was determined by dual X-ray absorptiometry (DXA).

T- and Z- scores were calculated from BMD. Definition of osteopenia/osteoporosis in the adult group was according to the WHO-criteria: Osteopenia: T-score between $<-1 \mathrm{SD}$ and $>-2.5 \mathrm{SD}$; Osteoporosis: T-score $<-2.5 \mathrm{SD}$. In the children group $<20$ years the guidelines from the International Society for Clinical Densitometry was used: Osteopenia: Z-score < -1 SD; Osteoporosis: Z-score $<-2.0 \mathrm{SD}$.

\section{Results}

Forty patients (75\%) had a normal DXA-SCAN, 7 patients $(13 \%)$ had osteopenia and 2 patients $(3,8 \%)$ had osteoporosis according to the described definitions.

$\mathrm{T}$-score for adults and Z-score for children were compared with normal reference values. There were no significant differences in the adult group. In children and adolescents younger than 20 years we found no significant differences in the Z-score of the whole body, but a marginally reduced Z-score of the lumbar spine.

The results are listed in Table 1.

Table 1 Bone Mineral Density Standard Deviation scores in 49 patients with JDM

\begin{tabular}{|c|c|c|c|c|c|c|}
\hline Score & $N$ & Patients & $\begin{array}{l}\text { Mean } \pm \\
S D\end{array}$ & Range & $\begin{array}{l}P \text { - } \\
\text { value* }^{*}\end{array}$ & $95 \% \mathrm{Cl}$ \\
\hline \multirow[t]{2}{*}{$\begin{array}{l}T \text { - } \\
\text { score }\end{array}$} & 23 & $\begin{array}{l}\text { Adults > } 20 \\
\text { years: } \\
\text { - Whole body } \\
\text { scan }\end{array}$ & $\begin{array}{l}0.43 \pm \\
1.1\end{array}$ & $\begin{array}{l}-1.6- \\
2.6\end{array}$ & 0.08 & $-0.05-0.9$ \\
\hline & & $\begin{array}{l}\text { Adults > } 20 \\
\text { years: } \\
\text { - Lumbar spine } \\
\text { scan }\end{array}$ & $\begin{array}{l}0.26 \pm \\
1.1\end{array}$ & $\begin{array}{l}-1.3- \\
2.1\end{array}$ & 0.29 & $\begin{array}{l}-0.24- \\
0.76\end{array}$ \\
\hline \multirow[t]{2}{*}{$\begin{array}{l}\text { Z- } \\
\text { score }\end{array}$} & 26 & $\begin{array}{l}\text { Children < } 20 \\
\text { years } \\
\text { - Whole body } \\
\text { scan }\end{array}$ & $\begin{array}{l}-0.02 \pm \\
0.8\end{array}$ & $\begin{array}{l}-2.0- \\
2.0\end{array}$ & 0.9 & $\begin{array}{l}-1.1-(-0- \\
04)\end{array}$ \\
\hline & & $\begin{array}{l}\text { Children }<20 \\
\text { years } \\
\text { - Lumbar spine } \\
\text { scan }\end{array}$ & $\begin{array}{l}-0.57 \pm \\
1.1\end{array}$ & $\begin{array}{l}-2.7- \\
1.6\end{array}$ & 0.04 & $-0.3-0.3$ \\
\hline
\end{tabular}

The table presents the mean $T$ - and Z-scores with SDs and range.

*P-values were calculated from the scores with One-Sample T-test

${ }^{1}$ Paediatrics, University Hospital, Holbaek, Denmark

Full list of author information is available at the end of the article 


\section{Conclusion}

In this JDM cohort $16.8 \%$ of the patients had osteopenia or osteoporosis. There were no significant differences in $\mathrm{T} / \mathrm{Z}$ - scores between the two groups, except for a marginally reduced $Z$-score of the lumbar spine scan in the JDM group younger than 20 years.

The results suggest that clinical follow-up with DXAscan is relevant for patients with JDM several years after disease remission.

\section{Disclosure of interest}

None declared.

\section{Authors' details}

${ }^{1}$ Paediatrics, University Hospital, Holbaek, Denmark. ${ }^{2}$ Paediatric Rheumatology Unit, Rigshospitalet, University Hospital, Copenhagen, Denmark. ${ }^{3}$ Paediatrics, University Hospital, Aarhus, Denmark.

Published: 5 December 2013

doi:10.1186/1546-0096-11-S2-P29

Cite this article as: Kristensen et al:: PReS-FINAL-2016: Bone mineral status in a long-term follow up of juvenile dermatomyositis patients. Pediatric Rheumatology 2013 11(Suppl 2):P29.

Submit your next manuscript to BioMed Central and take full advantage of:

- Convenient online submission

- Thorough peer review

- No space constraints or color figure charges

- Immediate publication on acceptance

- Inclusion in PubMed, CAS, Scopus and Google Scholar

- Research which is freely available for redistribution

Submit your manuscript at www.biomedcentral.com/submit 